\section{Reported Death}

\section{Marshall Ritter}

An ASHS member for more than 30 years, Dr. Crum Marshall Ritter passed away on January 3, 2009 at the age of 85. He was born in Washington, DC, attended high school in Anniston, AL, and obtained a BS in Vocational Agriculture, with a minor in Horticulture, from West Virginia University. He took time off from his undergraduate studies for military service during World War II in Africa, Sicily, and Italy and he received the Purple Heart and a Silver Star. He completed a MS degree in Horticulture from West Virginia University and received a $\mathrm{PhD}$ from The Ohio State University. He joined the Department of Horticulture at The Pennsylvania State University as an Assistant Professor in 1952; he was promoted to Associate Professor in 1957 and Professor in 1969. He was active in all three missions in the department. Early in his career Marshall taught graduate and undergraduate courses and advised graduate students. Later in his career he was the sole fruit extension spe- cialist for Pennsylvania. His research interests included all aspects of tree fruit production and postharvest handling, but he focused on nutrition, orchard soil management, and fruit variety evaluations. He also did applied research and gave lectures in several South American countries. Upon retirement in 1983, he formed an orchard consulting company and later became partner with his wife, Adelaide Morgan, in Morgan Orchard in Sinks Grove, WV.

RICHARD P. MARINI Department of Horticulture The Pennsylvania State University University Park

\title{
Corrigendum
}

In the Feb. 2009 issue of HortScience, the order of authors' names was incorrect in the article "Adjustment of Mineral Elements in the Culture Medium for the Micropropagation of Three Vriesea Bromeliads from the Brazilian Atlantic Forest: The Importance of Calcium" [HortScience 44(1):106-112]. The correct order of the authors' names, with their affiliations, is as follows:

\section{Adjustment of Mineral Elements in the Culture Medium for the Micropropagation of Three Vriesea Bromeliads from the Brazilian Atlantic Forest: The Importance of Calcium}

\author{
Alice Noemí Aranda-Peres \\ Universidade de São Paulo (USP), Centro de Energia Nuclear na Agricultura (CENA), Av. Centenário 303, Piracicaba, \\ SP, 13400-970, Brazil \\ Lázaro Eustáquio Pereira Peres \\ Universidade de São Paulo (USP), Escola Superior de Agricultura “Luiz de Queiroz” (ESALQ), Av. Pádua Dias 11, Piracicaba, \\ SP, 13418-970, Brazil \\ Edson Namita Higashi ${ }^{1}$ \\ Universidade de São Paulo (USP), Escola Superior de Agricultura “Luiz de Queiroz” (ESALQ), Av. Pádua Dias 11, Piracicaba, \\ SP, 13418-970, Brazil \\ Adriana Pinheiro Martinelli² \\ Universidade de São Paulo (USP), Centro de Energia Nuclear na Agricultura (CENA), Av. Centenário 303, Piracicaba, \\ SP, 13400-970, Brazil
}

